\title{
An analysis of pre-operative $\mathrm{PaO}_{2}$ in a general surgical population
}

\author{
M. L. DIAMENT A NDK. N. V. PALMER \\ From the Department of Medicine, University of Aberdeen
}

Two hundred and thirty one patients awaiting elective surgery were divided on the basis of spirometric examination into normal (group A) and those with increased airway resistance (group B). The mean arterial oxygen tension for the 151 normal subjects was $96 \cdot 3( \pm 11 \cdot 6) \mathrm{mm}$. $\mathrm{Hg}$. There was a significant inverse correlation of $\mathrm{PaO}_{2}$ with age and dynamic lung volumes. The 80 patients in group $\mathrm{B}$ were significantly older and their mean $\mathrm{PaO}_{2}$ was $88.7( \pm 12 \cdot 9) \mathrm{mm}$. $\mathrm{Hg}$. There was, however, no correlation between $\mathrm{PaO}_{2}$ and age in this group, probably because the increased airway resistance had a greater influence in lowering the arterial oxygen tension than did the age factor alone.

The increasing use of the oxygen electrode in clinical practice has awakened interest in the normal arterial oxygen tension $\left(\mathrm{PaO}_{2}\right)$. This is authoritatively stated to be $100 \mathrm{~mm} . \mathrm{Hg}$ (Roughton, 1964) but, until the normal range is known, the interpretation of the significance of single values under clinical conditions is uncertain. This is especially important in the post-operative patient, as the development of hypoxaemia can be expected in all patients after abdominal operations (Diament and Palmer, 1966). There are, however, few published reports of the $\mathrm{PaO}_{2}$ in patients awaiting surgery. Conway, Payne, and Tomlin (1965) found a mean $\mathrm{PaO}_{2}$ of $91.8( \pm 8.7)$ $\mathrm{mm}$. $\mathrm{Hg}$ for a group of 70 pre-operative patients who were clinically free of cardio-respiratory disease. We have measured the blood-gas tensions and carried out spirometric measurements on a group of patients who were undergoing elective abdominal surgery. None of these patients had any clinical evidence of cardio-respiratory disease and all were considered fit for major surgical procedures. However, subclinical respiratory impairment is often present in these patients (Diament and Palmer, 1967). Therefore, on the basis of spirometry, they were divided into two groups-group $\mathbf{A}$ in whom the forced expiratory volume in one second expressed as a percentage of the forced vital capacity (F.E.V. $1 \%$ ) was greater than 70 and who were considered, therefore, not to have increased airways resistance, and group B in whom the F.E.V. $\%$ was less than 70 and who were considered to have some obstruction to air flow. In both groups, an analysis was made to determine how the $\mathrm{PaO}_{2}$ varied with age, sex, height, weight, smoking habits, the dynamic lung volumes and the arterial carbon dioxide tension $\left(\mathrm{PaCO}_{2}\right)$.

\section{PATIENTS AND METHODS}

The number of men and women in the groups, their mean ages in years ( \pm S.D.), heights (in.), weights (lb.), and number of cigarettes smoked daily are shown in Table I.

T A B LE I

MEAN VALUES FOR AGE, HEIGHT, WEIGHT, AND SMOKING HABITS IN THE TWO GROUPS

\begin{tabular}{|c|c|c|c|c|c|}
\hline \multicolumn{3}{|c|}{ Measurement } & Group A & Group B & $\mathbf{P}$ \\
\hline $\begin{array}{l}\text { No. ... } \\
\text { Age (years) } \\
\text { Height (in.) } \\
\text { Weight (lb.) } \\
\text { Cigarettes/day }\end{array}$ & $\begin{array}{l}\ddot{ } \\
\ddot{*} \\
\because\end{array}$ & $\begin{array}{l}\cdots \\
\cdots \\
\cdots \\
\cdots\end{array}$ & $\begin{array}{c}\quad M \\
65 \\
43 \cdot 4 \pm 16 \cdot 8 \\
68 \cdot 0 \pm 2 \cdot 3 \\
154 \cdot 9 \pm 18 \cdot 3 \\
9 \cdot 1 \pm 10 \cdot 0\end{array}$ & $\begin{array}{c}57 \\
60 \cdot 3 \pm 9 \cdot 9 \\
67 \cdot 5 \pm 2 \cdot 9 \\
143 \cdot 5 \pm 25 \cdot 6 \\
9 \cdot 5 \pm 9 \cdot 5\end{array}$ & $\begin{array}{c}<0.001 \\
\text { N.S. } \\
\text { N.S. } \\
\text { N.S. }\end{array}$ \\
\hline $\begin{array}{l}\text { No. ... } \\
\text { Age (years) } \\
\text { Height (in.) } \\
\text { Weight (lb.) } \\
\text { Cigarettes/day }\end{array}$ & $\begin{array}{l}\cdots \\
\cdots \\
\cdots\end{array}$ & $\begin{array}{l}\cdots \\
\cdots \\
\cdots \\
\cdots\end{array}$ & $\begin{array}{c}86 \\
86 \\
45 \cdot 1 \pm 15 \cdot 9 \\
62 \cdot 9 \pm 2 \cdot 4 \\
130 \cdot 3 \pm 21 \cdot 7 \\
5 \cdot 4 \pm 7 \cdot 6\end{array}$ & $\begin{array}{c}23 \\
56 \cdot 8 \pm 15 \cdot 9 \\
62 \cdot 7 \pm 2 \cdot 8 \\
127 \cdot 7 \pm 19 \cdot 1 \\
7 \cdot 3 \pm 8 \cdot 5\end{array}$ & $\begin{array}{c}<0.005 \\
\text { N.S. } \\
\text { N.S. } \\
\text { N.S. }\end{array}$ \\
\hline
\end{tabular}

All the patients were interviewed soon after admission to the Aberdeen Royal Infirmary, when their agreement to take part in the study was obtained. The study was carried out when the patients were fully ambulant.

An arterial blood sample was obtained from the brachial artery into a heparin-lubricated syringe with the patient semi-recumbent. The patient was encouraged to relax and to breathe naturally, and 
the blood was allowed to fill the syringe under its own pressure. The sample was immediately immersed in a mixture of ice and water in a vacuum flask and the blood-gas tensions were measured in triplicate as soon as possible afterwards, using electrodes ${ }^{1}$ which were calibrated between each sample according to the manufacturer's instructions. The standard deviation for a single measurement for the oxygen electrode was $1.7 \mathrm{~mm} . \mathrm{Hg}$ and for the carbon dioxide electrode $1.2 \mathrm{~mm}$. $\mathrm{Hg}$.

A forced expiratory spirogram was recorded using the Vitalograph, also with the patient semi-recumbent, and the forced vital capacity (F.V.C.) and forced expiratory volume in 1 second (F.E.V.1) were calculated. At least three curves were recorded, the best being used for the calculation. Spirometric measurements were recorded at A.T.P.S. (ambient temperature and pressure, saturated).

\section{RESULTS}

The mean values ( \pm S.D.) for the blood-gas tensions and spirometric measurements are shown in Table II for the two groups.

The mean $\mathrm{PaO}_{2}$ for men in group $\mathrm{A}$ was $96 \cdot 1$ $( \pm 10 \cdot 9) \mathrm{mm}$. $\mathrm{Hg}$ and for women $96 \cdot 5( \pm 12 \cdot 1) \mathrm{mm}$. Hg. In group $\mathrm{B}$, the mean $\mathrm{PaO}_{2}$ for men was $90 \cdot 1$ $( \pm 12.5) \mathrm{mm}$. $\mathrm{Hg}$ and $85.3( \pm 13.7) \mathrm{mm}$. $\mathrm{Hg}$ for women. Both these mean values were significantly different from those in group $\mathbf{A}$, but the mean $\mathrm{PaO}_{2}$ was not significantly different between men and women in either group.

The mean $\mathrm{PaCO}_{2}$ for men in group $\mathrm{A}$ was 40.9 $( \pm 3.6) \mathrm{mm}$. $\mathrm{Hg}$ and for women $39.0( \pm 3.8) \mathrm{mm}$. $\mathrm{Hg}$, and this difference was significant $(\mathrm{P}<0.01)$. In group $\mathrm{B}$, the mean $\mathrm{PaCO}_{2}$ for men was $40 \cdot 7$ $( \pm 4 \cdot 3) \mathrm{mm}$. $\mathrm{Hg}$ and for women $40 \cdot 5( \pm 4 \cdot 1) \mathrm{mm}$. $\mathrm{Hg}$, which was not a significant difference.

'Manufactured by Radiometer, Copenhagen
T A B L E I I

MEAN VALUES FOR $\mathrm{PaO}_{2}, \mathrm{PaCO}_{2}$, F.E.V.V ${ }_{1}$ AND F.V.C. IN THE TWO GROUPS

\begin{tabular}{|c|c|c|c|c|}
\hline Measurement & & Group A & Group B & $\mathbf{P}$ \\
\hline $\begin{array}{l}\mathrm{PaO}_{2}(\mathrm{~mm} . \mathrm{Hg}) \\
\mathrm{PaCn}_{2}(\mathrm{~mm} . \mathrm{Hg}) \\
\text { F.E.V.1 (1., A.T.P.S.) } \\
\text { F.V.C.(1., A.T.P.S.) }\end{array}$ & $\begin{array}{l}\cdots \\
\because \\
\cdots\end{array}$ & $\begin{array}{r}M \\
96 \cdot 1 \pm 10 \cdot 9 \\
40 \cdot 9 \pm 3 \cdot 6 \\
3 \cdot 54 \pm 0 \cdot 79 \\
4 \cdot 49 \pm 0.94\end{array}$ & $\begin{array}{l}90 \cdot 1 \pm 12 \cdot 5 \\
4 \cdot 07 \pm 4 \cdot 3 \\
2 \cdot 31 \pm 0 \cdot 71 \\
3 \cdot 75 \pm 0 \cdot 97\end{array}$ & $\begin{array}{l}<0.01 \\
\text { N.S. } \\
<0.001 \\
<0.001\end{array}$ \\
\hline $\begin{array}{l}\mathrm{PaO}_{2}(\mathrm{~mm} . \mathrm{Hg}) \\
\mathrm{PacO}_{2} \text { (mm.Hg) } \\
\text { F.E.V.1 (1., A.T.P.S.) } \\
\text { F.V.C. (1., A.T.P.S.) }\end{array}$ & $\begin{array}{l}\because \\
\because \\
\cdots\end{array}$ & $\begin{array}{l}\quad W o \\
96 \cdot 5 \pm 12 \cdot 1 \\
39 \cdot 0 \pm 3 \cdot 8 \\
2 \cdot 36 \pm 0 \cdot 61 \\
2 \cdot 96 \pm 0 \cdot 68\end{array}$ & $\begin{array}{l}85 \cdot 3 \pm 13 \cdot 7 \\
40 \cdot 5 \pm 4 \cdot 1 \\
1 \cdot 40 \pm 0 \cdot 55 \\
2 \cdot 21 \pm 0 \cdot 82\end{array}$ & $\begin{array}{l}<0.001 \\
\text { N.S. } \\
<0.001 \\
<0.001\end{array}$ \\
\hline
\end{tabular}

The mean spirometric measurements were within $\pm 10 \%$ of the predicted normal values for men and women in group A. In group B, as might be expected, all the spirometric measurements were significantly lower than those in group A $(P<0.001)$ for men and women.

In Table III, correlation coefficients are given for $\mathrm{PaO}_{2}$ against the other variables for men and women in both groups, and regression equations are given where the correlation is a statistically significant one. In group A, for men and women, $\mathrm{PaO}_{2}$ correlated with age, F.E.V.1 ${ }_{\cdot 1}$ and F.V.C. In group $\mathrm{B}, \mathrm{PaO}_{2}$ correlated with F.E.V. $\cdot_{1}$ and F.V.C. in men only. The $\mathrm{PaO}_{2}$ did not correlate with height, weight or smoking habit in any of the groups. There was no correlation between $\mathrm{PaO}_{2}$ and $\mathrm{PaCO}_{2}$ except in women of group $\mathrm{A}$.

\section{DISCUSSION}

In this study there are two groups of patients who, on the basis of spirometric measurements, were divided into those who did not (group A) and those who did (group B) have evidence of increased airway resistance. Group B were older than group $\mathbf{A}$.

T A B L E I I I

CORRELATION COEFFICIENTS AND REGRESSION EQUATIONS

\begin{tabular}{|c|c|c|c|c|c|c|}
\hline \multirow{2}{*}{\multicolumn{3}{|c|}{$\mathrm{PaO}_{2} v$. }} & \multicolumn{2}{|c|}{ Men } & \multicolumn{2}{|l|}{ Women } \\
\hline & & & \multirow{2}{*}{$\begin{array}{c}\text { Group A } \\
\mathrm{PaO}_{2}=109.576(\mathrm{P}<0.001) \\
\end{array}$} & \multirow{2}{*}{$\frac{\text { Group B }}{-0.062 \text { (N.S.) }}$} & \multirow{2}{*}{$\begin{array}{c}\text { Group A } \\
-0.532(\mathrm{P}<0.001) \\
\mathrm{PaO}_{\mathbf{2}}=114.8-0.41 \text { (Age) }\end{array}$} & \multirow{2}{*}{$\frac{\text { Group B }}{-0 \cdot 282 \text { (N.S.) }}$} \\
\hline Age & . & $\cdots$ & & & & \\
\hline F.E.V.1. & $\cdots$ & . & $\begin{aligned} & +0.467(\mathrm{P}<0.001) \\
\mathrm{PaO}_{2} & =73.2+6.46 \text { (F.E.V.1 }\end{aligned}$ & $\begin{array}{c}+0.377(\mathrm{P}<0.01) \\
\left.\mathrm{PaO}_{2}=74.7+6.65 \text { (F.E.V.1 }\right)\end{array}$ & $\begin{aligned} & +0 \cdot 371(\mathrm{P}<0 \cdot 001) \\
\mathrm{PaO}_{2} & =79 \cdot 0+7 \cdot 41\left(\mathrm{~F} . \mathrm{E} . \mathrm{V}_{\cdot 1}\right)\end{aligned}$ & +0.293 (N.S.) \\
\hline F.V.C. . & $\cdots$ & $\cdots$ & $\begin{array}{c}+0.419(\mathrm{P}<0.001) \\
\mathrm{PaO}_{2}=74.1+4.88 \text { (F.V.C.) }\end{array}$ & $\begin{array}{c}+0 \cdot 371 \text { (P }<001) \\
\mathrm{PaO}_{2}=72 \cdot 1+4 \cdot 80 \text { (F.V.C.) }\end{array}$ & $\begin{array}{c}+0.315(\mathrm{P}<001) \\
\mathrm{PaO}_{2}=79 \cdot 8+5 \cdot 62 \text { (F.V.C.) }\end{array}$ & +0.386 (N.S.) \\
\hline $\mathrm{PaCO}_{2} \ldots$ & . & $\cdots$ & +0.082 (N.S.) & -0.233 (N.S.) & $\begin{array}{c}-0.262(\mathrm{P}<0.05) \\
\mathrm{PaO}_{2}=129.5-0.85\left(\mathrm{PaCO}_{2}\right)\end{array}$ & -0.104 (N.S.) \\
\hline Height ... & $\cdots$ & $\cdots$ & +0.074 (N.S.) & +0.134 (N.S.) & -0.171 (N.S.) & +0.261 (N.S.) \\
\hline Weight .. & $\cdots$ & $\cdots$ & -0.352 (N.S.) & +0.114 (N.S.) & -0.187 (N.S.) & +0.220 (N.S.) \\
\hline Cigarettes & & . & +0.157 (N.S.) & -0.044 (N.S.) & +0.091 (N.S.) & $+0 \cdot 188$ (N.S.) \\
\hline
\end{tabular}


The mean $\mathrm{PaO}_{2}$ for the normal group, men and women combined, was $96.3( \pm 11 \cdot 6) \mathrm{mm}$. $\mathrm{Hg}$. This is somewhat higher than that reported by Mellemgaard (1966), who found the mean $\mathrm{PaO}_{2}$ of 80 normal subjects to be $93 \cdot 1( \pm 8.0) \mathrm{mm}$. $\mathrm{Hg}$.

The mean $\mathrm{PaO}_{2}$ of the group $\mathrm{B}$ subjects was $88.7( \pm 12.9) \mathrm{mm}$. Hg. The difference between these means, $7.6 \mathrm{~mm}$. $\mathrm{Hg}$, is significant $(\mathrm{P}<0.001)$. Raine and Bishop (1963) found the mean $\mathrm{PaO}_{2}$ of subjects less than 40 years was $95.3( \pm 6.9) \mathrm{mm}$. $\mathrm{Hg}$, but for those above 40 years it was $88.2( \pm 9 \cdot 8)$ $\mathrm{mm}$. Hg. The mean age of our normal group was 44.3 years, whereas it was 58.6 years in group B, which suggests that age is an important factor in determining the lower mean $\mathrm{PaO}_{2}$ of this group. In the normal group the $\mathrm{PaO}_{2}$ was found in fact to correlate with age, which indicates that the $\mathrm{PaO}_{2}$ becomes less as age advances.

The regression equation we obtained for $\mathrm{PaO}_{2}$ against age for normal men was similar to that obtained by others for males and females combined (Raine and Bishop, 1963 ; Mellemgaard, 1966). The equation we obtained for normal women differed from that for men in that it showed a steeper slope and indicated that the $\mathrm{PaO}_{2}$ falls more rapidly with age in women than in men. Although this fall is not significantly different from that of the men, young women have a somewhat higher $\mathrm{PaO}_{2}$ level than young men, which we think is most likely due to hyperventilation. This is supported by our finding of a significantly lower $\mathrm{PaCO}_{2}$ level in women.

In normal subjects there is a statistically significant correlation between $\mathrm{PaO}_{2}$ and the dynamic lung volumes in both sexes. The consistency of these correlations indicates that the $\mathrm{PaO}_{2}$ is a sensitive indicator of ventilatory function, and that the $\mathrm{PaO}_{2}$ can be expected to be reduced whenever ventilatory function is impaired, whether the impairment is obstructive or restrictive in nature.

The $\mathrm{PaO}_{2}$ depends on the tension of oxygen in the alveoli $\left(\mathrm{PAO}_{2}\right)$, whether there is any barrier to diffusion of oxygen through the alveolar-capillary membrane and into the red cells, and on the degree of venous admixture or shunt effect from blood coming from areas of lung which are poorly ventilated although adequately perfused. In addition, blood from bronchial, pleural, and thebesian veins contributes to the venous admixture effect. The $\mathrm{PAO}_{2}$ depends on the inspired oxygen tension, the alveolar carbon dioxide tension $\left(\mathrm{PACO}_{2}\right)$ and the respiratory exchange ratio.

With advancing age, lung volumes diminish, there is a fall in compliance, the diffusing capacity diminishes (Cohn, Carroll, Amstrong, Shepard, and Riley, 1954), and there is an increase in the alveolar-arterial tension difference and in the physiological dead-space/tidal volume ratios (Raine and Bishop, 1963; Mellemgaard, 1966). Impaired diffusion becomes important at rest only when the $\mathrm{PAO}_{2}$ is much reduced, and as this value does not diminish with age, it is apparent that the fall in $\mathrm{PaO}_{2}$ with age is due to the increased inequalities of ventilation/perfusion ratios in the lungs of older subjects. This is supported by the absence of a significant correlation in normal men between $\mathrm{PaCO}_{2}$ and age $(\mathrm{r}=-0 \cdot 17)$, indicating that overall alveolar hypoventilation does not contribute to the falling $\mathrm{PaO}_{2}$ with increasing age in them. In women, on the other hand, there is a significant correlation between $\mathrm{PaCO}_{2}$ and age $(r=+0.24 ; \mathrm{P}<0.05)$, indicating that alveolar hypoventilation may contribute to the fall in $\mathrm{PaO}_{2}$ with age in them, and this added factor may well be the reason why the $\mathrm{PaO}_{2}$ declines more rapidly with age in women than in men. This might be thought to be associated with increased weight in older women, but the $\mathrm{PaCO}_{2}$ did not correlate significantly with weight in any of the four groups.

It is perhaps surprising that in neither men nor women was smoking (number of cigarettes per day) significantly correlated with any of the bloodgas tensions or spirometric measurements in either group. Nor was there a significant difference between the normal and abnormal groups in the number of cigarettes smoked per day. These findings may reflect the number of non-smokers in this series and the number of relatively light smokers.

We thank the consultant surgeons of Aberdeen Royal Infirmary for allowing us to examine the patients under their care, and Miss Senga MacRae for technical assistance.

\section{REFERENCES}

Cohn, J. E., Carroll, D. G., Armstrong, B. W., Shepard, R. H., and Riley, R. L. (1954). Maximal diffusing capacity of the lung in normal male subjects of different ages. J. appl. Physiol., 6,588 .

Conway, C. M., Payne, J. P., and Tomlin, P. J. (1965). Arterial oxygen tensions of patients awaiting surgery. Brit. J. Anaesth.,

Diament, M. L., and Palmer, K. N. V. (1966). Postoperative changes in gas tensions of arterial blood and in ventilatory function. Lancet, 2,180 . resistance. Lancet, 1, 1251 .

Mellemgaard, K. (1966). The alveolar-arterial oxygen difference: its size and components in normal man. Acta physiol. scand., 67, 10.

Raine, J. M., and Bishop, J. M. (1963). A-a difference in O, tension and physiological dead space in normal man. J. appl. Physiol.,

Roughton, F. J. W. (1964). Transport of oxygen and carbon dioxide. In Handbook of Physiology, Section 3.: Respiration, ed. Fenn W. O., and Rahn, H., Vol. 1, p. 767. Williams and Wilkins,
Baltimore. 